\title{
Impact of the Capital Structure Tools on the Performance Indicators in the Listed Companies in Tehran Stock Exchange
}

\author{
Mostafa Zangiabadi ${ }^{1, ~ *}$, Amin Rahimzade ${ }^{2}$, Mahdie Taboli ${ }^{3}$ \\ ${ }^{1}$ Faculty of Management and Accounting, Allame Tabatabaei University of Tehran, Tehran, Iran \\ ${ }^{2}$ Faculty of Management and Accounting, University of Qom, Qom, Iran \\ ${ }^{3}$ Scientific Group of Accounting, Department of Payame Noor University, Zangiabad, Iran \\ Email address: \\ m.zangiabadi229@gmail.com (M. Zangiabadi), a.rahimzade2002@gmail.com (A. Rahimzade), mhd.taboli@gmail.com (M. Taboli)
}

\section{To cite this article:}

Mostafa Zangiabadi, Amin Rahimzade, Mahdie Taboli. Impact of the Capital Structure Tools on the Performance Indicators in the Listed Companies in Tehran Stock Exchange. Journal of Investment and Management. Vol. 4, No. 5, 2015, pp. 204-209.

doi: $10.11648 /$ j.jim.20150405.20

\begin{abstract}
Today, one of the objectives of the financial managers is to maximize shareholder wealth, and in this context, determining the capital structure is a key factor. Due to tax benefits, the use of financial leverage is considered. On the other hand, due to higher interest costs associated with obtaining debt, bankruptcy may also exist. In conclusion, this study examines the impact of capital structure tools on the return on equity, return on assets and return on working capital. This paper examines the data from 2001 to 2011 companies listed in Tehran Stock Exchange. And the results after using the linear regression model, suggest that debt ratio is not affected on the return on equity, but is affected on the return on assets. while debt to net worth ratio and current and long-term debt to net worth ratio is affected on the return on equity. Also, the results show that debt to assets ratio and debt to net worth ratio and current and long-term debt to net worth ratio does not affect on the rate of return on working capital. And debt to net worth ratio and current and long-term debt to net worth ratio does not affect on the rate of return on assets. Overall, the results show that the capital structure affects on the performance of listed companies in Tehran stock exchange.
\end{abstract}

Keywords: Capital Structure, Debt Ratio, Debt to Net Worth Ratio, Debt to Assets Ratio, Return on Equity, Return on Assets, Return on Working Capital

\section{Introduction}

Capital structure, is the main topic at the finance of enterprises. There is not sufficient knowledge from the capital structure in the emerging markets and transition economies. Capital structure theories have tended to principles of evaluation and also play a developmental role in the stock markets[4]. Finance through an interest-bearing loan has benefits. First, interest on loan is an acceptable tax cost. And this will reduce the effective cost of loans and especially if the rate of return from the use of the loan is greater than the rate of financing costs shareholder, since the interest rate and principal on long-term loan is fixed, are not required to share the additional benefits with Lenders. and finally, because the lenders do not have the right to vote, shareholders can apply more control of the company with less money. On the other side, interest-bearing loans have some weak points as follows: First, on the one hand, the long-term interest-bearing debt make financial commitments and too much rely on it, increase the financial leverage and consequently, leads to increase the probability of bankruptcy and failure to pay the principal and interest on the loan. Especially in companies that do not live in good condition in view of the financial position, excessive use of long-term debt, outweigh the company's commitment and leads to increase the bankruptcy and financial risk and thereby damage to the shareholders. The second disadvantage of the use of the interest-bearing debt is by increasing the ratio of loans, creditors, to pay the loan, act with more cautious and also, due to the increasing of the loan payments risk, consider higher interest rates for loan payments that this issue will also affects on benefits from tax credits[3]. Therefore, this study investigates the effect of capital structure tools on the performance indicators at listed companies in Tehran Stock Exchange.

Capital structure represents a combination of debt and equity of the firms. Choosing the right combination of debt 
and equity, considered by many persons as company stakeholders, about the company's ability to continue and the potential impact of debt on the company's bankruptcy, and specifically is of interest to financial managers that their main mission is to maximize shareholder wealth. Thus, according to the methods of financing, the management to accomplish its goal, chooses one of the methods of financing or a combination of them with respect to advantages and disadvantages such the effect of stock returns on the firm's performance.

Thus, given the right combination of capital structure from the perspective of financial managers, identifying the effects that it has on firm performance has a particular importance.

In this study, we tried to examine the influences of the capital structure tools on performance indicators and the main research question is whether the capital structure tools (debt to asset ratio, debt to equity ratio, etc.) are effective on the performance indicators (ROE, ROA, ROWC) or not.

\section{The Theoretical Basis and Background of Research}

\subsection{Capital Structure}

There are different theories of capital structure and refer that the companies to finance and continue to operate consider three groups of resources: The first group resources that apparently does not have any costs include trade creditors and advances from Customers.

Second,are the internal financial resources that to finance through the second group requiered to the past profitability of the company that through the accumulation of past profits, the company provides a good source of financing that instead of dividing the earnings among the shareholders, use the earnings primarily in operational activities of company for higher yields.

And third, are the external financing such as bonds, loans and stocks. Of course the company may use these resources to short-term or long-term methods.

On the one hand, the existence of debt in the financial structure of firms because of the existence of the tax credits, thereby increasing earnings and consequently increase the return on equity and on the other hand, because of the existence of interest costs and the possibility of non-payment of debt at maturities, thereby increasing financial risk and reducing the market price per share, which consequently reduced the return on equity. The financial managers must choose the capital structure that has lower cost of capital that seek a better performance for companies. Therefore the financial managers must determine the weighted average cost of capital and the marginal cost of capital to determine the optimal capital structure. Managers should also determine the company's borrowing capacity by considering the incoming and outgoing cash flows, and then borrow by considering the other conditions. Optimal capital structure, is the following: determining the percentages of items that formed the capital that minimize the weighted average cost of capital of the company and thus to maximize the returns of company [19].

\subsection{Theories of the Capital Structure}

\subsubsection{Modigliani and Miller Approach}

These two scientists, in their theory with the assumption that the capital market is complete and the investors like the corporations can borrow and at a cost equal to companies studied the relationship between leverage and the firm value under the assumption of tax and no tax.

A) The Absence of Tax:

In the complete capital markets, the debt can not affect firm value, now that the debt does not increase the share value, investors instead of buying leveraged company shares, purchase the non-leveraged company shares that have less risk and personally borrow and invest in a combination of stocks and personal loans.

B) The Existence of Tax

Using the debt because of the debt interest cost is acceptable tax cost create a tax advantage for the company and increasing the tax advantage, reduced capital costs and thus increase the value of the company [15].

\subsubsection{A New Approach}

In the new approach, it is believed that there are many factors that the companies consider to determine the level of the debt and stocks. There are different theories that explain this issue includes:

A) The Preference Theory:

The enterprises initially prefer the internal financing. The company initially uses the retained earnings and cash from the company to finance. If they have more need, initially issue bonds and finally issue common shares.

B) The static trade-off theory:

According to this theory, the companies determine a debt ratio(optimal) and use various methods to keep the optimal debt ratio. The optimal debt ratio of a company is determined based on the balance between costs and benefits of borrowing. And the company will try to balance between the tax credits and bankruptcy costs of debt [15].

\subsubsection{Signaling Theory}

Due to the fact that managers often have more information to the outside investors of the company that this is a case of asymmetric information that has a major impact on the desirable capital structure. Thus, firms that have undesirable future ahead, tend to sell the shares to new investors to partner them at the cost. While companies that have a very good future do not provide capital needed through the sale of the new shares. Therefore declaration of shares offering usually see as a warning signal that the directors do not see the company's future very bright or shining [18].

\subsection{Prior Related Literature}

Shirzad (2001) in a study entitled The effect of capital structure on profitability of listed companies in Tehran Stock Exchange, found that there is not a strong and significant relationship between capital structure and profitability of 
listed companies in Tehran Stock Exchange[17].

Ebadi Dowlatabadi (2002) in a study entitled The effect of methods of financing on yields and price of shares of companies listed in Tehran Stock Exchange, found that the impact of issue of shares than the long-term debt, on the stock price is more. Also capital increases Compared with bank borrowings has a greater impact on stock returns[5].

Bahrami Kia(2003) in a study entitled The effect of capital structure on the capital cost and the market price of shares of companies listed in Tehran Stock Exchange for the food industry, found that the capital structure (debt ratio) does not affect on the cost of capital and the market price of shares and the total market value of the surveyed companies[2]

Izad Nia and Rahimi dastjerdi (2009), in a study entitled the impact of capital structure on the stock returns and earnings per share, concluded that there is meaningful relation between the debt-equity ratio and return on equity and earnings per share and also there is a significant relationship between the debt to asset ratio with earnings per share[7]

Khajavi and colleagues (2010),in a study pay to evaluate the effect of capital structure on the cumulative abnormal yields of companies listed in Tehran Stock Exchange. The results show that the capital structure does not meaningful influence on the cumulative abnormal yields. Also the systematic risk, P / E, BTM and firm size have positive and significant effect on the cumulative abnormal yields[10]

Izzie and Saidi (2012), in a study pay to evaluate the relationship between capital structure and performance of companies listed in Tehran Stock Exchange for the pharmaceutical companies during the years 2003-2010. And the results of their analysis shows that there is a significant relationship between the variables of capital structure, debt ratio, return on equity and corporate performance[8]

Antoniou et al (2002), in a research under the title the determinants of firms' capital structure, examined the impact of leverage Ratio on the capital structure and achieved to results that the companies configured the factors affecting on capital structure to achieve the optimal capital structure [1]

Another study by Mateus and Balla (2002) was performed in the selection of the optimal capital structure. They have used regression analysis of mixed data for 55 companies from 1995 to 1999 and concluded that the firm's size is directly related to leverage[11]

Richardson and Sloan (2003) in a study under the title the relationship between external financing with future stock returns, review all of the external financing and found there is a negative relationship between the changes in the net external financing and expected stock returns. They finally realized that predict future stock returns is largely dependent on the capital structure[16]

El-Sayed Ebaid (2009), in a study under the title The impact of capital-structure choice on firm performance: empirical evidence from Egypt Based on a sample of non-financial corporations during the years 1997-2005 And resulted that the capital structure decisions overall have low to the zero limit effect on firm performance[6]
Chakraborty (2010), in a study investigate the capital structure in an emerging stock market in India that his research results show that among the three theories of capital structure, seems that Hierarchical theory and the theory of information asymmetry vindicate the financing decisions of Hindi firms. However, little evidence supports the costs of agency theory [4]

Muradoglu and Sivaprasad (2012) in a study under the title Capital structure and abnormal returns examine the relationship between capital structure and abnormal stock returns and the results show that the average abnormal returns in the parts manufacturing industry increase risky and considered the characteristics of the industry in his research. This irregular behavior has seen in competitive and irregular industries and the low concentration. The classification of the risk of facilities increase abnormal efficiency in parts manufacturing companies that are similar to the findings of Miller and Modigliani (1958) [13].

Jin $\mathrm{Xu}$ (2012), in a study under the title profitability and capital structure showed that the results of information asymmetry approach (model) of capital structure, predicts a positive relationship between leverage and coming profitability. Their research evidence suggests that internal competitions affects on leverage through the change in the balance the tax benefits arising from debt and financing costs resulting from the sale of assets [9]

\section{Research Hypotheses}

The first hypothesis (original): There is an association between the capital structure and the performance of the firms listed in Tehran Stock Exchange.

The second hypothesis (sub-prime): There is an association between the debt to assets ratio and the return on equity.

The third hypothesis (sub-second): There is an association between the debt to net worth ratio and the return on equity.

The fourth hypothesis (sub-third): There is an association between the current debt to net worth ratio and the return on equity.

The fifth hypothesis (sub-fourth): There is an association between the Long-term debt to net worth ratio and the return on equity.

The sixth hypothesis (sub-fifth): There is an association between the debt to assets ratio and the return on assets.

The seventh hypothesis (sub-sixth): There is an association between the debt to net worth ratio and the return on assets.

The eighth hypothesis (sub-seventh): There is an association between the current debt to net worth ratio and the return on assets.

The ninth hypothesis (sub-eighth): There is an association between the Long-term debt to net worth ratio and the return on assets.

The tenth hypothesis (sub-ninth): There is an association between the debt to assets ratio and the return on working capital.

The eleventh hypothesis (sub-tenth): There is an association between the debt to net worth ratio and the return on working capital. 
The twelfth hypothesis (sub-eleventh): There is an association between the current debt to net worth ratio and the return on working capital.

The thirteenth hypothesis (sub-twelfth): There is an association between the Long-term debt to net worth ratio and the return on working capital.

\section{Methodology}

This research regarding the type is analytic and regarding the target is applied. Library resources and literature on this subject are used to write the theoretical foundation and the main body of the research and data are collected by available software in the library of Tehran Stock Exchange and were collected the Information listed companies from 2001 to 2011. By calculating the research variables and logistic regression analysis between them, have tested the research hypotheses using SPSS software.

\subsection{Data Collection Methods}

There are several methods of data collection. In a study may be used of several methods to collect information. In this study are used of literature methods to literature review, in this method was studied literature and sources used in the research of their products. Into analysis obtained data are used of descriptive statistics and inferential statistics. Data analysis after collecting and organizing data and tests has been done with using, SPSS and Minitab software.

\subsection{Research Community}

Research population have been all listed companies in Tehran Stock Exchange for the years 2001-2011 that have been submitted the required financial information in particular its explanatory notes to the Stock Exchange.

\subsection{Research Sample}

Samples selected for analysis is all the companies that provide the data needed, and have the following conditions:

- They have been active In the 2001-2011 period in the stock exchange.

- They have provided the financial ratios fully.

- It is the fiscal year ending in March.

- They have not included holding companies and credit financial institutions and banks.

\section{Research Findings}

Table 1 shows the results of the descriptive statistics, such as mean and standard deviation of the variables.

Table 1. The results of descriptive statistics.

\begin{tabular}{lll}
\hline standard deviation & mean & Type of variable \\
\hline 620 & 15.65 & return on assets \\
1163.36 & 68.66 & return on equity \\
6578.92 & -48.51 & return on working capital \\
1.41 & 0.83 & debt to assets ratio \\
70.25 & 0.51 & debt to net worth ratio \\
\hline
\end{tabular}

\begin{tabular}{lll}
\hline standard deviation & mean & Type of variable \\
\hline 16.63 & -0.04 & Long-term debt to net worth ratio \\
58.11 & 0.53 & current debt to net worth ratio \\
\hline
\end{tabular}

According to Table 2, the significance level of the F statistic is 0.000 , which indicates a regression model is significant at $99 \%$ confidence level. And the Adjusted $\mathrm{R}^{2}$ equal to $1 \%$, which suggests that about $1 \%$ of the variation in Performance of firms is due to the change in the capital structure. The significance level of the statistic $t$ (probability of independent variable) is equal to 0.000 , which indicates at confidence level of $95 \%$ capital structure affects on firm performance.

The results of the first hypothesis:

Table 2. The results of the statistical test of the first hypothesis.

\begin{tabular}{lllllll}
\hline sig. & t & beta & sig. & F & Adjusted R2 & R2 \\
\hline 0.000 & -6.84 & -6.882 & 0.000 & 46.793 & 0.01 & 0.01 \\
\hline
\end{tabular}

According to Table 3, the significance level of the F statistic is 0.850 , which indicates a regression model is not significant at $99 \%$ confidence level. And the Adjusted R2 equal to 0.000 , which suggests that the variation in return on equity is not due to the change in the debt to assets ratio. The significance level of the statistic $\mathrm{t}$ (probability of independent variable) is equal to 0.850 , which indicates at confidence level of $95 \%$ debt to assets ratio does not affect on return on equity.

The results of the second hypothesis:

Table 3. The results of the statistical test of the second hypothesis.

\begin{tabular}{lllllll}
\hline sig. & t & beta & sig. & F & Adjusted $\mathbf{R}^{2}$ & $\mathbf{R}^{\mathbf{2}}$ \\
\hline 0.850 & 0.189 & -2.296 & 0.85 & 0.036 & 0.000 & 0.000 \\
\hline
\end{tabular}

According to Table 4, the significance level of the F statistic is 0.000 , which indicates a regression model is significant at 99\% confidence level. And the Adjusted R2 equal to 0.390, which suggests that about $39 \%$ of the variation in return on equity is due to the change in the debt to net worth ratio. The significance level of the statistic $t$ (probability of independent variable) is equal to 0.000 , which indicates at confidence level of $95 \%$ debt to net worth ratio affects on return on equity.

The results of the third hypothesis:

Table 4. The results of the statistical test of the third hypothesis.

\begin{tabular}{lllllll}
\hline sig. & t & beta & sig. & F & Adjusted $\mathbf{R}^{\mathbf{2}}$ & $\mathbf{R}^{\mathbf{2}}$ \\
\hline 0.0 & -54.14 & -10.36 & 0.000 & 2939 & 0.389 & 0.39 \\
\hline
\end{tabular}

According to Table 5, the significance level of the F statistic is 0.000 , which indicates a regression model is significant at 99\% confidence level. And the Adjusted R2 equal to 0.380, which suggests that about $38 \%$ of the variation in return on equity is due to the change in the current debt to net worth ratio. The significance level of the statistic $t$ (probability of independent variable) is equal to 0.000 , which indicates at confidence level of $95 \%$ current debt to net worth ratio affects on return on equity.

The results of the fourth hypothesis: 
Table 5. The results of the statistical test of the fourth hypothesis.

\begin{tabular}{lllllll}
\hline sig. & t & beta & sig. & F & Adjusted R & R $^{2}$ \\
\hline 0.000 & -53.146 & -12.343 & 0.000 & 2824.5 & 0.380 & 0.380 \\
\hline
\end{tabular}

According to Table 6, the significance level of the F statistic is 0.000 , which indicates a regression model is significant at 99\% confidence level. And the Adjusted R2 equal to 0.232 , which suggests that about $23 \%$ of the variation in return on equity is due to the change in the long-term debt to net worth ratio. The significance level of the statistic t (probability of independent variable) is equal to 0.000 , which indicates at confidence level of $95 \%$ long-term debt to net worth ratio affects on return on equity.

The results of the fifth hypothesis:

Table 6. The results of the statistical test of the fifth hypothesis.

\begin{tabular}{lllllll}
\hline sig. & t & beta & sig. & F & Adjusted $\mathbf{R}^{\mathbf{2}}$ & $\mathbf{R}^{\mathbf{2}}$ \\
\hline 0.000 & -37.343 & -33.727 & 0.000 & 1394.50 & 0.232 & 0.23 \\
\hline
\end{tabular}

According to Table 7, the significance level of the F statistic is 0.035 , which indicates a regression model is not significant at $99 \%$ confidence level. And the Adjusted R2 equal to 0.001, which suggests that about $0.1 \%$ of the variation in return on assets is due to the change in the debt to asset ratio. The significance level of the statistic $t$ (probability of independent variable) is equal to 0.035 , which indicates at confidence level of $95 \%$ debt to asset ratio affects on return on assets.

The results of the sixth hypothesis:

Table 7. The results of the statistical test of the sixth hypothesis.

\begin{tabular}{lllllll}
\hline sig. & $\mathbf{t}$ & bata & sig. & $\mathbf{F}$ & Adjusted $\mathbf{R}^{2}$ & $\mathbf{R}^{2}$ \\
\hline 0.035 & -2.10 & -13.607 & 0.035 & 4.426 & 0.001 & 0.001 \\
\hline
\end{tabular}

According to Table 8, the significance level of the F statistic is 0.944 , which indicates a regression model is not significant at $99 \%$ confidence level. And the Adjusted R2 equal to 0.000, which suggests that the variation in return on assets is not due to the change in the debt to net worth ratio. The significance level of the statistic $t$ (probability of independent variable) is equal to 0.944 , which indicates at confidence level of $95 \%$ debt to net worth ratio does not affect on return on assets.

The results of the seventh hypothesis:

Table 8. The results of the statistical test of the seventh hypothesis.

\begin{tabular}{lllllll}
\hline sig. & t & beta & sig. & F & Adjusted R & $\mathbf{R}^{2}$ \\
\hline 0.944 & 0.070 & 0.009 & 0.944 & 0.005 & 0.000 & 0.000 \\
\hline
\end{tabular}

According to Table 9, the significance level of the F statistic is 0.945 , which indicates a regression model is not significant at $99 \%$ confidence level. And the Adjusted R2 equal to 0.000, which suggests that the variation in return on assets is not due to the change in the current debt to net worth ratio. The significance level of the statistic $t$ (probability of independent variable) is equal to 0.945 , which indicates at confidence level of $95 \%$ current debt to net worth ratio does not affect on return on assets.

The results of the eighth hypothesis:
Table 9. The results of the statistical test of the eighth hypothesis.

\begin{tabular}{lllllll}
\hline sig. & t & beta & sig. & F & Adjusted $\mathbf{R}^{2}$ & $\mathbf{R}^{\mathbf{2}}$ \\
\hline 0.945 & 0.068 & 0.011 & 0.945 & 0.005 & 0.000 & 0.000 \\
\hline
\end{tabular}

According to Table 10, the significance level of the $\mathrm{F}$ statistic is 0.953 , which indicates a regression model is not significant at $99 \%$ confidence level. And the Adjusted R2 equal to 0.000 , which suggests that the variation in return on assets is not due to the change in the long-term debt to net worth ratio. The significance level of the statistic $t$ (probability of independent variable) is equal to 0.953 , which indicates at confidence level of $95 \%$ long-term debt to net worth ratio does not affect on return on assets.

The results of the ninth hypothesis:

Table 10. The results of the statistical test of the ninth hypothesis.

\begin{tabular}{lllllll}
\hline sig. & t & beta & sig. & F & Adjusted R & $\mathbf{R}^{\mathbf{2}}$ \\
\hline 0.953 & 0.059 & 0.032 & 0.953 & 0.003 & 0.000 & 0.000 \\
\hline
\end{tabular}

According to Table 11, the significance level of the $\mathrm{F}$ statistic is 0.808 , which indicates a regression model is not significant at 99\% confidence level. And the Adjusted R2 equal to 0.000 , which suggests that the variation in return on working capital is not due to the change in the debt to asset ratio. The significance level of the statistic $t$ (probability of independent variable) is equal to 0.808 , which indicates at confidence level of $95 \%$ debt to asset ratio does not affect on return on working capital.

The results of the tenth hypothesis:

Table 11. The results of the statistical test of the tenth hypothesis.

\begin{tabular}{lllllll}
\hline sig. & t & beta & sig. & F & Adjusted $\mathbf{R}^{\mathbf{2}}$ & $\mathbf{R}^{\mathbf{2}}$ \\
\hline 0.808 & 0.244 & 16.722 & 0.808 & 0.059 & 0.000 & 0.000 \\
\hline
\end{tabular}

According to Table 12, the significance level of the $\mathrm{F}$ statistic is 0.997 , which indicates a regression model is not significant at $99 \%$ confidence level. And the Adjusted R2 equal to 0.000 , which suggests that the variation in return on working capital is not due to the change in the debt to net worth ratio. The significance level of the statistic $t$ (probability of independent variable) is equal to 0.997 , which indicates at confidence level of $95 \%$ debt to net worth ratio does not affect on return on working capital.

The results of the eleventh hypothesis:

Table 12. The results of the statistical test of the eleventh hypothesis.

\begin{tabular}{lllllll}
\hline sig. & t & beta & sig. & F & Adjusted R & $\mathbf{R}^{2}$ \\
\hline 0.997 & 0.004 & 0.005 & 0.997 & 0.000 & 0.000 & 0.000 \\
\hline
\end{tabular}

According to Table 13, the significance level of the $\mathrm{F}$ statistic is 0.998 , which indicates a regression model is not significant at 99\% confidence level. And the Adjusted R2 equal to 0.000 , which suggests that the variation in return on working capital is not due to the change in the current debt to net worth ratio. The significance level of the statistic $t$ (probability of independent variable) is equal to 0.998 , which indicates at confidence level of $95 \%$ the current debt to net worth ratio does not affect on return on working capital. 
The results of the twelfth hypothesis:

Table 13. The results of the statistical test of the twelfth hypothesis.

\begin{tabular}{lllllll}
\hline sig. & t & beta & sig. & F & Adjusted $\mathbf{R}^{\mathbf{2}}$ & $\mathbf{R}^{\mathbf{2}}$ \\
\hline 0.998 & 0.003 & 0.005 & 0.998 & 0.000 & 0.000 & 0.000 \\
\hline
\end{tabular}

According to Table 14, the significance level of the $\mathrm{F}$ statistic is 0.995 , which indicates a regression model is not significant at $99 \%$ confidence level. And the Adjusted R2 equal to 0.000 , which suggests that the variation in return on working capital is not due to the change in the long-term debt to net worth ratio. The significance level of the statistic $t$ (probability of independent variable) is equal to 0.995 , which indicates at confidence level of $95 \%$ the long-term debt to net worth ratio does not affect on return on working capital.

The results of the thirteenth hypothesis:

Table 14. The results of the statistical test of the thirteenth hypothesis.

\begin{tabular}{lllllll}
\hline sig. & t & beta & sig. & F & Adjusted R & $\mathbf{R}^{\mathbf{2}}$ \\
\hline 0.995 & 0.006 & 0.034 & 0.995 & 0.000 & 0.000 & 0.000 \\
\hline
\end{tabular}

\section{Discussion and Conclusions}

The test results of hypotheses indicate that the debt to assets ratio does not affect the return on equity, but affect the return on assets. While the debt to net worth ratio and current and long-term debt to net worth ratio affect the return on equity. Also The results show that the debt to assets ratio and the debt to net worth ratio and current and long-term debt to net worth ratio does not affect the return on working capital. Also the debt to net worth ratio and current and long-term debt to net worth ratio does not affect the return on assets. Overall, the results suggest that capital structure affect the performance listed companies in Tehran stock exchange.

\section{Suggestions}

In this research from the financial statements data of listed companies in Tehran Stock Exchange has been used and suggested that in the future studies use the financial statements data of OTC. In this research were examined the information from the financial statements for the years 2001 to 2011. And suggested that in the future studies use from the another time interval. It is suggested that in the future studies use other factors than the rate of return on assets, return on equity and return on capital as the performance indicators.

\section{References}

[1] Antoniou; Antonio's, G.; Paudyal 2002. Determinants of Corporate Capital structure: Evidence From European Countries, social science research network. www.ssrn.com $\backslash$ abstract $=285001$

[2] Bahrami Kia, G. 2003. The effect of capital structure on cost of capital and the market price of shares of companies listed in
Tehran Stock Exchange for the food industry, MS Thesis, University of Isfahan, IRAN

[3] Berry, G.; O-Jean F.; Gapnsky; dyvez 2003. The Intermediate Financial Management, Translated by Ali Parsayyan, Tehran, Terme

[4] Chakraborty, I. 2010. Capital structure in an emerging stock market: The case of India, Research in International Business and Finance 24: 295-314

[5] Ebadi Dowlatabadi, M. 2002. The effect of the methods of financing (external sources) on the yield and price of shares of companies listed in Tehran Stock Exchange, MS Thesis, University of Mazandaran, IRAN

[6] El-Sayed Ebaid, I. 2009. The impact of capital-structure choice on firm performance: empirical evidence from Egypt, Journal of Risk Finance, 10 (5): 477 - 487

[7] Izadi nia, N.; Dastjerdi Rahimi M. 2009. The effect of capital structure on the rate of return on equity and earnings per share, Accounting Research, 3: 136-161

[8] Izzie, R.; Saeedi, P. 2012. The relationship between capital structure and the performance of companies listed in Tehran Stock Exchange, The National Conference of modern management science, september 2012

[9] Jin Xu. 2012. Profitability and capital structure: Evidence from import penetration, Journal of Financial Economics 106: $427-446$

[10] Khajavi, S.; Valipur, H.; Hakemi, B. 2010. The effect of capital structure on the cumulative abnormal returns of companies listed in Tehran Stock Exchange, Financial Studies, No. 5

[11] Mateus, D.; Balla 2002. Optimal capital structure, social science research network, www.ssrn.com $\backslash$ abstract $=277019$

[12] Miglo, A. 2010. Capital structure and earnings manipulation, Journal of Economics and Business 62: 367-382

[13] Muradoglu, Y. G. I.; Sivaprasad, SH. 2012. Capital structure and abnormal returns, International Business Review 21: $328-341$

[14] Omran, M.; Pointon, J. 2009. Capital structure and firm characteristics: an empirical analysis from Egypt, Review of Accounting and Finance, 8(4):454 - 474

[15] Qalibafe asl, H. 2010. The Financial Management (principles, concepts and applications), Eighth Edition, Tehran, Pooran Pajoohesh

[16] Richardson, S.; sloan2003. External financing and future stock returns, the rodeneyl.white center for financial research, www.ssrn.com $\backslash$ abstract $=285008$

[17] Shirzad, J. 2001. The effect of capital structure on profitability of listed companies in Tehran Stock Exchange. MS Thesis, University of Shiraz, IRAN

[18] Yu Jin, F.; Brigham; Earhart, M.C. 1930. Financial Management in Theory and Practice, translated by Alireza Farahani, Tehran, Terme, 2012

[19] Zahmatkesh, J. 2005. The assessing the nature of the capital structure and its impact on stock returns of companies operating in the cement industry in the years 1998-2002, MA thesis, University of Science and Research, Tehran, IRAN. 